\title{
KEBIJAKAN REKLAMASI PANTAI DAN LAUT: IMPLIKASI TERHADAP HAK MASYARAKAT PESISIR DAN UPAYA PERLINDUNGANNYA
}

\author{
Flora Pricilla Kalalo ${ }^{1}$
}

\begin{abstract}
Abstrak
The purpose of this research is to know of the implication of coastal and sea reclamation towards coastal people and to know the available efforts of protection as well as protection that should be performed. By benefiting primary legal materials such as legislation regulations and international conventions as well as secondary legal materials such as text books, court decisions, experts' opinion, research results, journals, internet sources and non-legal materials, it can be concluded that coastal and sea reclamation possessed urgent implication on the coastal people's rights so protection is necessary towards the coastal people through the establishment of special act concerning coastal and sea reclamation, arranging the reclamation comprehensively, comprising the adat law community, local as well as urban community rights, also regulating the requirements, planning, performing, protection and/or compensation of the people as well as ordering conserving the function of the environment.
\end{abstract}

Kata kunci: hukum sumber daya alam, kebijakan, reklamasi pantai dan laut, masyarakat pesisir,

\section{Pendahuluan}

Sekalipun Indonesia belum memiliki suatu undang-undang tersendiri yang secara khusus mengatur tentang reklamasi, tetapi telah ada sejumlah peraturan yang berkenaan dengan reklamasi pantai dan laut, walaupun secara partial. Peraturan-peraturan tersebut mencakup:

1. Pasal 34 UU No 27 Tahun 2007 tentang Pengelolaan Wilayah Pesisir dan Pulau-pulau Kecil. Melalui pasal ini diberikan: 1) kepastian hukum terhadap pelaksana reklamasi pantai, yaitu reklamasi pantai merupakan pranata hukum yang sah, walaupun

${ }^{1}$ Dosen Fakultas Hukum dan Program Studi Ilmu Hukum Pascasarjana Universitas Sam Ratulangi, Manado. 
harus dengan memperhatikan sejumlah syarat; dan 2) kepastian hukum terhadap masyarakat, yang terdiri dari Masyarakat Adat dan Masyarakat Lokal yang bermukim di Wilayah Pesisir dan Pulau-Pulau Kecil (Pasal 1 butir 32), berupa jaminan keberlanjutan kehidupan dan penghidupan masyarakat (Pasal 34 ayat (2) huruf a). Tidak tercakup dalam pasal ini masyarakat perkotaan.

2. Pasal 12 PP Nomor 16 Tahun 2004 tentang Penatagunaan Tanah yang menentukan bahwa tanah yang berasal dari tanah timbul atau hasil reklamasi di wilayah perairan pantai, pasang surut, rawa, danau, dan bekas sungai dikuasai langsung oleh Negara. Dalam Pasal ini diberikan kepastian hukum terhadap keabsahan tanah hasil reklamasi, walaupun sampai pada ketentuan bahwa tanah itu dikuasai langsung oleh negara.

Pasal-pasal di atas menunjukkan bahwa reklamasi pantai merupakan suatu hal yang tidak dapat ditolak pelaksanaannya oleh masyarakat, kecuali mungkin oleh masyarakat hukum adat dengan mengajukan keberatan terhadap Pasal 34 UU No.27 Tahun 2007 sebagai bertentangan dengan Pasal 18B ayat (2) UUD 1945. Masyarakat lokal dan masyarakat perkotaan, sepanjang bukan merupakan masyarakat hukum adat maupun masyarakat lokal, memiliki kedudukan yang lebih lemah dalam menghadapi pelaksanaan reklamasi pantai.

Dalam tulisan ini dikaji apakah implikasi pelaksanaan reklamasi pantai dan laut terhadap masyarakat pesisir dan apakah upaya perlindungan yang telah ada maupun yang masih perlu dilakukan.

\section{Hak Masyarakat Pesisir}

Masyarakat pesisir adalah masyarakat yang bermukim di wilayah pesisir. Dalam UU No. 27 Tahun 2007 tentang Pengelolaan Wilayah Pesisir dan Pulau-pulau Kecil, pengertian masyarakat pesisir memiliki pengertian yang khusus. Menurut Pasal 1 butir 32 undang-undang ini, masyarakat (pesisir) adalah "masyarakat yang terdiri dari Masyarakat Adat dan Masyarakat Lokal yang bermukim di Wilayah Pesisir dan Pulau-Pulau Kecil." Jadi lingkup perhatian terhadap masyarakat pesisir dalam UndangUndang ini hanya mencakup masyarakat adat ${ }^{2}$ dan masyarakat lokal saja.

${ }^{2}$ Dalam UUD 1945 digunakan istilah masyarakat hukum adat; yaitu menurut Pasal 18B ayat (2) UUD 1945: "Negara mengakui dan menghormati kesatuan-kesatuan masyarakat hukum adat beserta hak-hak tradisionalnya sepanjang masih hidup dan sesuai dengan 
Hak-hak tradisional dari masyarakat hukum adat amat luas dan beraneka ragam. Dalam Naskah Akademik Pengelolaan Wilayah Pesisir, yang dibuat dalam rangka penyusunan Rancangan Undang-Undang tentang Pengelolaan Wilayah Pesisir, dikemukakan adanya Hak Masyarakat Adat (tradisional) seperti: Hak Ulayat Laut, Hak Kepemilikan Masyarakat Adat, dan Sasi Laut di Maluku. ${ }^{3}$ Dalam lingkup internasional, secara khusus eksistensi hak masyarakat tradisional terhadap tanah dan kampung halamannya dirumuskan dalam dokumen Perserikatan Bangsa-Bangsa No. E/CN.4/2002/97. Substansi yang lebih rinci dari hak masyarakat tradisional ini dapat ditemukan dalam ILO Convention concerning Indigenous and Tribal Peoples in independent Countries Nomor 169 tahun 1989 tanggal 27 juni 1989. ${ }^{4}$ Di Indonesia, Indigenous and Tribal Persons dikenal sebagai masyarakat hukum adat. Dalam suasana hukum adat, masing-masing masyarakat hukum adat, yang merupakan subyek-subyek hukum, mempunyai sejumlah hak. Hak ini oleh Pasal 18B ayat (2) Undang-Undang Dasar 1945 disebut sebagai "hak-hak tradisionalnya".

Masyarakat lokal adalah kelompok masyarakat yang menjalankan tata kehidupan sehari-hari berdasarkan kebiasaan yang sudah diterima sebagai nilai-nilai yang berlaku umum tetapi tidak sepenuhnya bergantung pada Sumber daya Pesisir dan Pulau-Pulau Kecil tertentu (Pasal 1 butir 34 UU No.27 Tahun 2007).

Mengenai riwayat pengunaan istilah masyarakat lokal, dalam Naskah Akademik Pengelolaan Pesisir dan Laut Sulawesi Utara dikemukakan bahwa, dalam proses penyusunan draft Ranperda Minahasa, diajukan pertanyaan dengan melihat syarat-syarat teoritis suatu masyarakat hukum adat, apakah di Minahasa masih ada masyarakat hukum adat, sehingga untuk menghindari perdebatan teoritis, akhirnya dalam Perda Minahasa digunakan istilah

perkembangan masyarakat dan prinsip Negara Kesatuan Republik Indonesia, yang diatur dalam undang-undang." Supaya konsisten dengan Undang-Undang Dasar 1945, selanjutnya secara tetap akan digunakan istilah masyarakat hukum adat sekalipun yang dibahas adalah masyarakat hukum adat yang bermukim di wilayah wilayah. Supaya konsisten dengan Undang-Undang Dasar 1945, selanjutnya secara tetap akan digunakan istilah masyarakat hukum adat sekalipun yang dibahas adalah masyarakat hukum adat yang bermukim di wilayah pesisir.

${ }^{3}$ Anonimous, 2001. Naskah Akademik Pengelolaan Wilayah Pesisir. Dirjen Pesisir dan Pulau-Pulau Kecil Departemen Kelautan dan Perikanan, Jakarta, hal. IV-15, IV-16.

${ }^{4}$ Rizani Puspawidjaja, "Hak Sosial Budaya Masyarakat Tradisional dalam Perspektif Kekinian. Memaknai Sengketa Hak Atas Tanah Sebagai Sebuah Hak Yang Bersifat Asasi," dalam H. Muladi (ed), 2005. Hak Asasi Manusia. Hakekat, Konsep dan Implikasinya dalam Perspektif Hukum dan Masyarakat. Refika Aditama, Bandung, h. 241. 
masyarakat lokal." ${ }^{5}$ Hakekat dari istilah masyarakat lokal yaitu masyarakat lokal mencakup masyarakat hukum adat (jika ada di Propinsi Sulawesi Utara) dan masyarakat semi-masyarakat hukum adat, yaitu mereka yang menjalankan tatanan hukum, sosial dan budaya yang ditetapkan dan ditaati oleh mereka sendiri secara turun-temurun. Dengan kata lain, pada masyarakat yang bersangkutan masih melekat hukum adat sekalipun masyarakat itu tidak sepenuhnya lagi merupakan suatu masyarakat hukum adat.

Dalam Undang-Undang Nomor 27 Tahun 2007, hak masyarakat lokal ini sudah tercakup dalam Pasal 60 ayat (1), di mana dalam Pasal 60 ayat (1) ini hanya disebut tentang "masyarakat". Dengan hanya menyebut "masyarakat" berarti ketentuan berlaku untuk masyarakat (hukum) adat dan masyarakat lokal.

Di kawasan perkotaan, masyarakat yang bermukim di wilayah pesisir, pada umumnya bukan merupakan masyarakat hukum adat dan juga bukan masyarakat lokal dalam arti tadi. Masyarakat pesisir perkotaan seperti ini, yang bukan masyarakat hukum adat atau masyarakat lokal, tidak dicakup oleh pengaturan dalam UU No. 27 Tahun $2007 .{ }^{6}$ Di lain pihak, merupakan kenyataan bahwa reklamasi pantai dan laut pada umumnya dilakukan di pesisir perkotaan dengan dalih meningkatkan perekonomian. Jadi mereka ini yang justru sering berhadapan dengan kegiatan reklamasi tersebut. Dengan demikian, masyarakat pesisir kawasan perkotaan, sepanjang bukan merupakan masyarakat hukum adat atau masyarakat lokal/semi-masyarakat hukum adat, hanya mendapatkan perlindungan secara perseorangan berdasarkan adanya kerugian yang nyata pada yang bersangkutan.

5 Anonimous, 2002. Naskah Akademik Pengelolaan Pesisir dan Laut Sulawesi Utara. DPRD Provinsi Sulawesi Utara-Fakultas Hukum Universitas Sam Ratulangi-Proyek Pesisir Sulawesi Utara, Manado, tidak dipublikasi, h. 43.

${ }^{6}$ Dalam diskusi antara Sarwono Kusumaatmadja dengan tim dari Fakultas Hukum Universitas Sam Ratulangi dan Proyek Pesisir Sulut, tanggal 28 Juni 2002, bertempat di Fakultas Hukum Unsrat, oleh Sarwono Kusumaatmadja dikemukakan bahwa dengan Perda Minahasa, hukum adat telah dihidupkan kembali. Tetapi, Kota Manado misalnya tidak boleh mengikuti model Minahasa karena masyarakat Manado merupakan masyarakat urban dan tidak punya masyarakat adat (Ibid., h.60). 


\section{Implikasi Kebijakan Reklamasi Pantai dan Laut Terhadap Hak Masyarakat Pesisir}

Kebijakan reklamasi pantai di Indonesia telah dilaksanakan dibeberapa daerah di Indonesia, dari penelitian ini melalui studi kepustakaan dan pengamatan dilapangan bahwa kebijakan reklamasi pantai dan laut memang memberikan dampak perubahan pola hidup masyarakat maupun perubahan terhadap lingkungan. Pada pengamatan, untuk reklamasi di Kota Manado dampak terhadap anggota masyarakat yang bermukim di pesisir, yaitu:

1. Sejumlah anggota masyarakat yang berprofesi sebagai nelayan, pada awalnya terpaksa setiap hari memikul perahu mereka dari tepi laut, menyeberang daerah yang sedang direklamasi, melintas jalan raya Pierre Tendean, dan sampai di depan rumah sendiri di mana mereka meletakkan perahunya. Beberapa bulan kemudian perahu-perahu itu tidak lagi kelihatan, mereka berganti profesi dengan membuka warung, rumah makan sederhana, tempat jualan pisang goreng, dan sebagainya, karena Jalan Pierre Tendean sudah makin ramai.

2. Pada saat sedang dilakukan reklamasi pantai, pernah masyarakat setempat mengajukan protes karena mereka mendapat penyakit mata merah disebabkan debu yang beterbangan. Jalan keluarnya truk pengangkut tanah hanya bekerja di malam hari, sedangkan di sore hari jalan raya disiram air oleh pemadam kebakaran sehingga debu tidak lagi beterbangan.

3. Untuk area di mana dilakukan reklamasi, tidak dilakukan pembebasan tanah sehingga masyarakat tetap bermukim di tempat semula. Tetapi kelihatan ada pemilik-pemilik baru yang membangun toko dengan jalan membeli dari masyarakat dengan harga yang sudah meningkat karena jalur rumah penduduk yang semula di dalam kampung di tepi pantai sekarang berubah menjadi di tepi jalan raya.

Pelibatan masyarakat pesisir dalam kegiatan reklamasi adalah masih bersifat amat terbatas, yaitu hanya sebagai tenaga kerja pada tahap konstruksi pengembangan, yaitu sebagai buruh bangunan, dan sebagai karyawan toko, dan sebagainya, pada saat tahap operasi lahan reklamasi. Sampai saat ini masyarakat pesisir masih dipandang sebagai pihak yang berada di luar kegiatan reklamasi, tidak mempunyai hak untuk mengajukan keberatan, dan karenanya selalu diabaikan dalam upaya reklamasi, kecuali sebagai tenaga kerja semata-mata. 
Dampak negatif dari kebijakan pembangunan di kawasan pesisir seperti halnya kegiatan reklamasi memang tidak bisa terhindar selain perubahan pola hidup dari masyarakat terjadi juga kerusakan habitat ekosistem di wilayah pesisir dan laut, khususnya di wilayah padat kegiatan seperti di beberapa kota pantai di Indonesia yang melakukan proyek reklamasi. Rusaknya habitat ekosistem pesisir seperti deforestasi hutan mangrove serta terjadinya degradasi sebagian besar terumbu karang memang tidak terelakan lagi. Padahal sebagian kegiatan reklamasi sebagai implementasi dari kebijakan pemerintah untuk menghentikan erosi pantai namun akibatnya menimbulkan berkurangnya keanekaragaman hayati (biodiversity). Erosi ini juga diperburuk oleh perencanaan tata ruang dan pengembangan wilayah yang kurang tepat akibat egoisme sektoral dalam memanfaatkan pantai dan perairannya. Sementara itu, laju sedimentasi yang merusak perairan pesisir juga terus meningkat. disebabkan oleh kegiatan di lahan atas yang tidak dilakukan dengan benar, bahkan mengabaikan asas konservasi tanah. Di samping itu, tingkat pencemaran di beberapa kawasan pesisir dan laut juga berada pada kondisi yang sangat memprihatinkan.

Dari aspek hak-hak masyarakat pesisir, berbagai hak dari masyarakat pesisir sebagaimana dikemukakan sebelumnya cenderung menjadi terdesak dengan adanya kebijakan reklamasi pantai dan laut. Dengan kata lain, kebijakan reklamasi, apalagi setelah didukung oleh ketentuan Pasal 34 Undang-Undang Nomor 27 Tahun 2007 tentang Pengelolaan Wilayah Pesisir dan Pulau-pulau Kecil, memiliki implikasi mendesak hak-hak masyarakat pesisir.

\section{Upaya Perlindungan Terhadap Masyarakat Pesisir}

Beberapa hal yang perlu diperhatikan, yang mencakup tataran teori hukum dan tataran peraturan, dalam upaya perlindungan terhadap masyarakat pesisir berkenaan dengan reklamasi pantai dan laut, yaitu pertama, seharusnya kebijakan yang dibuat dapat bermanfaat bagi masyarakat banyak. Bentham dengan prinsip-prinsip umum dari pendekatan utilitarian ke dalam kawasan hukum, mengatakan bahwa manusia itu akan berbuat dengan cara sedemikian rupa sehingga ia mendapatkan kenikmatan yang sebesarbesarnya dan menekan serendah-rendahnya penderitaan. Standar penilaian etis yang dipakai di sini adalah apakah suatu tindakan itu menghasilkan kebahagiaan. ${ }^{7}$ Mertupakan kenyataan bahwa kebijakan reklamasi pantai dan House, 1968).

${ }^{7}$ Edwin M. Schur, "Law and Society, A Sociologikal View", (New York: Random 
laut di beberapa kota di Indonesia, banyak mengabaikan hak-hak masyarakat pesisir yang mendiami kawasan tersebut, padahal menurut Bentham hukum bertujuan untuk mewujudkan apa yang berfaedah atau yang sesuai dengan kepentingan orang banyak, pernyataannya adalah the greatest happiness of the greatest number, kebahagiaan yang terbesar untuk jumlah yang terbanyak, artinya setiap kebijakan yang diambil oleh pemerintah harus memperhatikan kepentingan masyarakat pesisir, bukan hanya kepentingan investor.

Kedua, teori John Rawls: justice as fairness yang merupakan penjabaran lebih lanjut dari keadilanb distributif. Dalam bukunya $A$ Theory of Justice, 1971, Rawls mengemukakan tentang justice as fairness, yang dimaksudkannya sebagai alternatif terhadap doktrin-doktrin keadilan yang telah lama mendominasi filsafat, yaitu konsep-konsep keadilan menurut doktrin utilitarianisme dan intuisionis. ${ }^{8}$ Digunakannya istilah keadilan sebagai fairness karena istilah ini dapat mencerminkan gagasan Rawls bahwa prinsip-prinsip keadilan disepakati dalam suatu situasi yang fair. ${ }^{9}$ Dalam hal ini, Rawls berangkat dari teori kontrak sosial sebagaimana yang diungkapkan oleh Locke, Rousseau, dan Kant, di mana dalam keadaan alamiah (state of nature, status naturalis), ada posisi kesetaraan asali ${ }^{10}$ (original position of equality) antara orang-orang. Posisi kesetaraan asali ini oleh Rawls dipandang sebagai situasi yang fair untuk mulai dilakukannya kesepakatankesepakatan guna memilih asas-asas yang akan diterima bersama, antara lain asas keadilan.

Menurut Rawls, orang-orang dalam situasi awal ini akan memilih dua prinsip yang agak berbeda; pertama membutuhkan kesetaraan dalam penerapan hak dan kewajiban dasar, kedua menyatakan bahwa ketimpangan sosial dan ekonomi, misalnya ketimpangan kekayaan dan kekuasaan, hanyalah jika mereka menghasilkan kompensasi keuntungan bagi semua

${ }^{8}$ John Rawls, 1971. A Theory of Justice. The Belknap Press of Harvard University Press, Cambridge, Massachusetts, h.3: "I also take up, for purposes of clarificationand contrast, the classical utilitarian and intuitionist conceptions of justice and consider some of the difference between these views and justice as fairness. My guiding aim is to work out a theory of justice that is a viable alternative to these doctrines which have long dominated our philisophycal tradition."

${ }^{9}$ Ibid., hal. 12.

${ }^{10}$ Istilah posisi kesetaraan asali digunakan dalam John Rawls, 2006. Teori Keadilan, terjemahan Uzair Fauzan dan Heru Prasetyo dari A Theory of Justice. Pustaka Pelajar, Yogyakarta, h.13, sebagai terjemahan dari istilah the original position of equality dari John Rawls, 1971, Loc. Cit. 
orang khususnya bagi anggota masyarakat yang paling tidak beruntung." Berdasarkan pembahasan selanjutnya, inti pandangan Rawls adalah bahwa keadilan sebagai fairness terdiri atas dua asas, yaitu: a. Asas kebebasan (liberty principle), yaitu setiap orang mempunyai hak yang sama atas kebebasan dasar yanbg paling luas, seluas kebebasan serupa dari orang-orang lain; b. Asas perbedaan (difference principle), yaitu ketimpangan sosial dan ekonomi harus diatur sedemikian rupa sehingga memenuhi dua hal: (1) semua posisi dan jabatan terbuka bagi semua orang menurut syarat-syarat kesetaraan peluang yang fair (fair equality of opportunity); dan, (2) keuntungan terbesar untuk anggota-anggota masyarakat yang paling tidak beruntung. ${ }^{12}$

Ketiga, yaitu Pasal 18B ayat (2) UUD 1945 yang menentukan bahwa Negara mengakui dan menghormati kesatuan-kesatuan masyarakat hukum adat beserta hak-hak tradisionalnya sepanjang masih hidup dan sesuai dengan perkembangan masyarakat dan prinsip Negara Kesatuan Republik Indonesia, yang diatur dalam undang-undang. Melalui pasal ini diberikan kepastian hukum terhadap kesatuan-kesatuan masyarakat hukum adat beserta hak-hak tradisionalnya.

Keempat, yaitu adanya ketentuan tentang Tanggung Jawab Sosial dan Lingkungan dari Korporasi. Terlebih dahulu di Amerika Serikat dikenal adanya konsep Tanggung Jawab Sosial (Social Responsibility), yaitu suatu teori etika bahwa suatu sosok (entity) baik suatu pemerintah, korporasi, organisasi, maupun individual mempunyai suatu tanggung jawab terhadap masyarakat. Tanggung jawab ini dapat bersifat "negatif", berupa suatu tanggung jawab untuk menahan diri dari bertindak (keadaan menahan diri) atau bersifat "positif", berupa suatu tanggung jawab untuk bertindak (keadaan proaktif). ${ }^{13}$ Tanggung jawab sosial ada pada Pemerintah, Korporasi (corporation), Organisasi, dan Individu. Khususnya berkenaan dengan korporasi, dikenal istilah Tanggung Jawab Sosial Korporasi (Corporate

${ }^{11}$ John Rawls, 2006, Op. Cit., hal.16.

12 "Justice as Fairness consists of two principles: First, each person is to have an equal right to the most extensive basic liberty compatible with similar liberty for others. Second, "Social and economic inequalities are to satisfy two conditions: (a) They are to be attached to positions and offices open to all under conditions of fair equality of opportunity; and (b), they are to be to the greatest benefit of the least advantaged members of society." The first of these two principles is known as the liberty principle, while the second half, reflecting the idea that inequality is only justified if it is to the advantage of those who are less well-off, is known as the difference principle" <http://en.wikipedia.org/wiki/Justice_as_Fairness>, kunjungan 20-9-2008.

${ }^{13}<$ http://en.wikipedia.org/wiki/Social_responsibility $>$. 
Social Responsibility), yang dalam Wikipedia (2008b) diberikan keterangan bahwa Tanggung Jawab Sosial Korporasi (Corporate Social Responsibility) adalah suatu konsep di mana organisasi-organisasi memperhatikan kepentingan-kepentingan masyarakat dengan memikul tanggung jawab atas dampak dari aktivitas mereka terhadap konsumen, karyawan, pemegang saham, komunitas, dan lingkungan dalam semua aspek dari operasi mereka. Kewajiban ini dipandang lebih luas daripada kewajiban hukum berdasarkan peraturan perundang-undangan dan menghendaki agar organisasi-organisasi secara suka rela mengambil langkah-langkah lebih lanjut untuk meningkatkan kualitas hidup karyawan dan keluarga mereka sebagaimana juga terhadap komunitas lokal dan masyarakat pada umumnya. ${ }^{14}$

Di Indonesia, ada sejumlah peraturan perundang-undangan yang telah menentukan bagian-bagian tertentu dari tanggung jawab dan kewajiban moral dalam konsep Tanggung Jawab Sosial Korporasi sebagai tanggung jawab dan kewajiban hukum, sehingga bukan lagi semata-mata sebagai tanggung jawab dan kewajiban moral semata-mata. Yang paling luas adalah ketentuan dalam UU Nomor 40 Tahun 2007 tentang Perseroan Terbatas, di mana digunakan istilah "tanggung jawab sosial dan lingkungan". Pada bagian Penjelasan Umum diberikan keterangan bahwa dalam UndangUndang ini diatur mengenai Tanggung Jawab Sosial dan Lingkungan yang bertujuan mewujudkan pembangunan ekonomi berkelanjutan guna meningkatkan kualitas kehidupan dan lingkungan yang bermanfaat bagi Perseroan itu sendiri, komunitas setempat, dan masyarakat pada umumnya. Ketentuan ini dimaksudkan untuk mendukung terjalinnya hubungan Perseroan yang serasi, seimbang, dan sesuai dengan lingkungan, nilai, norma, dan budaya masyarakat setempat, maka ditentukan bahwa Perseroan yang kegiatan usahanya di bidang dan/atau berkaitan dengan sumber daya alam wajib melaksanakan Tanggung Jawab Sosial dan Lingkungan. Untuk melaksanakan kewajiban Perseroan tersebut, kegiatan Tanggung Jawab Sosial dan Lingkungan harus dianggarkan dan diperhitungkan sebagai biaya Perseroan yang dilaksanakan dengan memperhatikan kepatutan dan kewajaran. Kegiatan tersebut dimuat dalam laporan tahunan Perseroan. Dalam hal Perseroan tidak melaksanakan Tanggung Jawab Sosial dan Lingkungan maka Perseroan yang bersangkutan dikenai sanksi sesuai dengan ketentuan peraturan perundang-undangan.

Berikutnya yakni tanggung jawab dan kewajiban yang dirumuskan dalam Pasal 34 ayat (2) Undang-Undang Nomor 27 Tahun 2007, yang merupakan bagian-bagian dari Tanggung Jawab Sosial Korporasi yang telah diwujudkan dalam peraturan-peraturan hukum sehingga telah menjadi

${ }^{14}<$ http://en.wikipedia.org/wiki/Corporate_social_responsibility $>$. 
tanggung jawab dan kewajiban hukum. Selanjutnya adalah tanggung jawab dan kewajiban yang dirumuskan dalam Pasal 16 Keppres Nomor 33 Tahun 2002 tentang Pengendalian dan Pengawasan Pengusahaan Pasir Laut ${ }^{15}$ yang menentukan bahwa setiap orang dan/atau badan hukum yang melakukan pengusahaan pasir laut wajib menyusun rencana pemberdayaan masyarakat pesisir (ayat 1). Pelaksanaan pemberdayaan masyarakat pesisir sebagaimana dimaksud dalam ayat (1) dikoordinasikan oleh Pemerintah Daerah sesuai dengan kewenangan masing-masing berdasarkan ketentuan peraturan perundang-undangan (ayat 2). Pembiayaan yang timbul dari pelaksanaan rencana pemberdayaan masyarakat pesisir sebagaimana dimaksud dalam ayat (2) dibebankan kepada orang dan/atau badan hukum yang melakukan pengusahaan pasir laut (ayat 3). Dalam Pasal 16 ayat (1) Keputusan Presiden ini ditetapkan salah satu bentuk perlindungan hukum untuk masyarakat pesisir yang wajib dilaksanakan oleh pengusaha pasir laut, yaitu pemberdayaan masyarakat pesisir. Untuk itu pengusaha pasir wajib menyusun rencana pemberdayaan masyarakat pesisir. Pelaksanaan pemberdayaan pesisir ini dikoordinasikan oleh Pemerintah Daerah (ayat 2), sedangkan pembiayaan yang timbul dari pelaksanaan rencana pemberdayaan masyarakat pesisir dibebankan kepada orang dan/atau badan hukum yang melakukan pengusahaan pasir laut. Lebih lanjut dapat dijelaskan bahwa berdasarkan Keputusan Presiden Nomor 33 Tahun 2002 itu, untuk melaksanakan pengendalian dan pengawasan terhadap pengusahaan pasir laut dibentuk Tim Pengendali dan Pengawas Pengusahaan Pasir Laut, salah satu tugasnya mengkoordinasikan dan merekomendasikan penetapan pedoman pemanfaatan dana pemulihan lingkungan ekosistem pesisir dan laut serta dana pemberdayaan masyarakat pesisir, dan melakukan monitoring, evaluasi, serta pengawasan (Pasal 5 ayat (1) huruf 3 Keputusan Presiden).

Kelima, yaitu Konservasi Ekosistem Sumber Daya Alam di Wilayah Pesisir. Wilayah Indonesia, yang dideklarasikan pada tanggal 13 Desember 1957 dan diterima menjadi bagian dari hukum laut internasional (UNCLOS, 1982), menjadikan Indonesia sebagai negara kepulauan terbesar di dunia dengan 17,000 pulau dan memiliki wilayah laut terluas, jumlah pulau terbanyak, dan pantai $81.000 \mathrm{~km}$ yang terpanjang kedua di dunia setelah Canada, dan letak geografis Indonesia yang berada di khatulistiwa, di antara dua benua dan dua samudera menempatkan Indonesia sebagai negara maritim yang sangat strategis dengan kekayaan alam laut yang melimpah. Keadaan Wilayah Indonesia yang seperti disadari sebagai kekuatan sekaligus

15 Penambangan pasir laut merupakan suatu hal yang banyak ditentang, tetapi disebutnya Keppres ini untuk melihat konsep tanggung jawab sosial dan lingkungan korporasi di dalamnya. 
kelemahan, karena memberikan peluang serta ancaman bagi kebijakan pembangunan di berbagai bidang, baik di bidang sosial dan budaya, ekonomi industri, wilayah, lingkungan hidup, pertahanan keamanan, maupun hukum dan aparatur negara. Terlebih lagi mengingat Kekayaan alam dan keanekaragaman hayati yang terdapat laut berlimpah jumlahnya sehingga pendayagunaannya harus dilakukan secara bertanggungjawab untuk kemakmuran rakyat.

Berkaitan dengan penelitian ini, kebijakan reklamasi pantai menjadi bagian yang tak terpisahkan dari program pembangunan pesisir. Dampak negatif dari kebijakan reklamasi pantai terasa pengaruhnya pada kerusakan ekosistem pesisir pantai dan laut termasuk struktur lingkungan yang semula pantai dan laut berubah menjadi daratan menjadi bagian dari dampak perubahan lingkungan yang tak terelakan dalam kebijakan reklamasi pantai.

Ancaman perusakan lingkungan akibat dari proses pembangunan memang menjadi bagian yang tak terelakan dalam kebijakan reklamasi pantai. Konsep yang mengagung-agungkan pengembangan kawasan dari yang tidak produktif menjadi produktif menjadi bagian yang terpenting dalam kebijakan reklamasi ini, namun dalam kenyataannya konsep tersebut tidak mampu mengimbangi dampak kerusakan lingkungan yang disebabkan oleh pembangunan di wilayah pesisir dan seharusnya bukan merupakan konsep pembangunan yang bijaksana karena menyampingkan konsep pembangunan berkelanjutan yang berwawasan lingkungan. Dalam kaitan dengan ini, konservasi ekosistem sumber daya hayati di wilayah pesisir dan laut penting menjadi bagian dari kebijakan lingkungan dalam menghadapi aktivitas perusakan sumber daya pesisir dan laut. Aktivitas tersebut meliputi pencemaran dari aktivitas pemukiman, pertanian, industri, perikanan, penambangan pasir laut dan pembangunan di wilayah pesisir.

Mengkritisi hal ini, maka konservasi ekosistem sumber daya hayati di wilayah pesisir pantai dan laut harus menjadi bagian yang tidak terpisahkan dalam kebijakan pembangunan di wilayah pesisir pantai dan laut karena konservasi sumber daya hayati laut merupakan salah satu implementasi pengelolaan ekosistem sumber daya laut dari kerusakan akibat aktivitas manusia. Sekalipun kawasan konservasi ini dilindungi oleh hukum, semisalnya dengan Kepres No. 32 Tahun 1990, tentang Pengelolaan Kawasan Lindung, namun perlu kesadaran bersama antara pemerintah dan masyarakat untuk mewujudkan terciptanya kawasan konservasi ini.

Dalam lingkup internasional, hubungan antara pembangunan dan lingkungan juga tidak pernah lepas dari perhatian. Berbagai pertemuan internasional dilakukan secara berkala sebagaimana dikatakan oleh Jorgen Wettestad di tahun 1999 bahwa United Nations Special Session 1997 sebagai kelanjutan dari UN Conference on Environment and Development 1992 
menandai fakta bahwa telah lewat dua dekade sejak Stockholm United Nations Conference on the Human Environment 1972. ${ }^{16}$ Aktivitas lebih lanjut dari rangkaian temu internasional di atas, yaitu Report of the World Summit on Sustainable Development, Johannesburg, South Africa, 26 August-4 September 2002.

Dari perspektif hukum dan kebijakan kerusakan sumber daya alam (SDA) dan pencemaran lingkungan hidup cenderung disebabkan oleh paradigma politik hukum yang dianut pemerintah untuk mengelola SDA dan lingkungan hidup. Secara konkret paradigma ini dapat dilihat dari instrumen hukum (legal instrument) yang digunakan pemerintah untuk mengatur penguasaan dan pengelolaan SDA dan lingkungan hidup. Jika dicermati secara kritis maka ditemukan fakta hukum bahwa substansi dari produk hukum negara (state law) dalam bentuk perundang-undangan mengenai pengelolaan SDA yang ada cenderung bernuansa sentralistik, bersifat sektoral, bercorak represif, dan mengedepankan pendekatan sekuriti (security approach). ${ }^{17}$

Instrumen hukum yang mencerminkan karakteristik seperti di atas, sentralistik, sektoral, dan represif, selain tidak memberikan perlindungan bagi kelestarian dan keberlanjutan fungsi SDA, juga kurang memberi ruang bagi pengakuan dan perlindungan akses serta hak-hak masyarakat adat/lokal atas penguasaan dan pemanfaatan SDA. Implikasi dari kondisi-kondisi seperti di atas secara ekologi menimbulkan degradasi kuantitas maupun kualitas SDA (ecological loss); dari segi ekonomi membatasi akses dan bahkan telah menghilangkan sumber-sumber masyarakat adat/lokal (economic resource loss); dari segi sosial budaya secara nyata telah merusak sistem pengetahuan, teknologi, institusi, religi, dan tradisi kearifan masyarakat adat/lokal (social and cultural loss); dan dari segi politik hukum menggusur atau mengabaikan fakta kemajemukan hukum dalam pengelolaan SDA (political of legal pluralism ignorance). ${ }^{18}$

Keenam, yaitu Zonasi Kawasan Pesisir dan Laut. Zonasi merupakan bagian dari konservasi lingkungan, yang terfokus pada sistem pengendalian penggunaan lahan di wilayah pesisir melalui pengelolaan pembangunan

${ }^{16}$ Jorgen Wettestad,. "Designing Effective Environmental Regime", (Northampton, Massachusetts: Edward Elgar Publishing, , 1999), hal. 1.

${ }^{17}$ I Nyoman Nurjaya, 2008. "Pengelolaan Sumber Daya Alam dalam Perspektif Antropologi Hukum", (Jakarta: Prestasi Pustaka Publisher), hal. 94-95.

${ }^{18}$ I Nyoman Nurjaya, 2000. "Proses Pemiskinan Di Sektor Sumber Daya Alam: Perspektif Politik Hukum", dalam ICRAF dan JAPHAMA, Masyarakat Adat dalam Mengelola Sumber Daya Alam, Bogor. 
berkelanjutan pada kawasan pertemuan darat laut yang oleh pemerintah harus ditetapkan peruntukannya sesuai ketentuan yang berlaku tanpa mengabaikan pelestarian lingkungan dan hak-hak masyarakatnya. Zonasi bertujuan menyediakan perlindungan bagi habitat kritis, ekosistem dan proses-proses ekologi; memisahkan kegiatan manusia yang bertentangan dan melindungi kualitas budaya dan alam pesisir dan laut.

Disadari bahwa industri modern memberikan kemakmuran material yang tak tertandingi sepanjang sejarah namun juga menciptakan juga ancaman-ancaman lingkungan baik bagi generasi sekarang maupun generasi yang akan datang. Teknologi memungkinkan manusia memanipulasi dan mengendalikan alam juga mencemari lingkungan dan dengan cepat menghabiskan persediaan sumber daya alam. Sejak awal abad 21 ada beberapa kecenderungan yang menentukan nasib peradaban manusia di antaranya berkurangnya wilayah perikanan dan punahnya sejumlah species hewan dan tanaman. Padahal manusia sangat tergantung pada hasil laut untuk memperoleh ketersediaan pangan. ${ }^{19}$ Oleh karenanya, zonasi merupakan sesuatu yang perlu dilakukan.

Sehubungan dengan ini menarik untuk memperhatikan peraturan daerah Hong Kong berkenaan dengan reklamasi pantai. Reklamasi pantai diatur dalam Foreshore and Seabed (Reclamation) Ordinance, tetapi kemudian dibuat Protection of the Harbour Ordinance. Pembuatan Protection of the Harbour Ordinance ini bertujuan untuk melindungi pelabuhan Hong Kong dari kegiatan reklamasi yang berlebihan. Pada Pasal 3 Protection of the Harbour Ordinance ditentukan:

Section 3: Presumption against reclamation in the harbour

(1) The harbour is to be protected and preserved as a special public asset and a natural heritage of Hong Kong people, and for that purpose there shall be a presumption against reclamation in the harbour. (Amended 75 of 1999 s. 4)

(2) All public officers and public bodies shall have regard to the principle stated in subsection (1) for guidance in the exercise of any powers vested in them. ${ }^{20}$

${ }^{19}$ Manuel G. Velasques, 2005. Etika Bisnis. Konsep dan Kasus, terjemahan Anna Purwasingsih et al dari Business Ethics, Conceps and Cases. Andi, Yogyakarta, h. 250, 252.

${ }^{20}$ Hong Kong Ordinance Cap 531: Protection of the Harbour Ordinance. 
Dalam Pasal 3 ini diletakkan asas praduga menolak reklamasi di pelabuhan (presumption against reclamation in the harbour). Dalam ayat (1) dikemukakan bahwa pelabuhan perlu dilindungi dan dipertahankan sebagai suatu aset publik yang khusus dan suatu warisan alamiah rakyat Hong Kong, dan untuk tujuan itu ditetapkan suatu praduga menolak reklamasi di pelabuhan. Selanjutnya dalam ayat (2) ditegaskan bahwa semua pejabat dan badan publik harus memperhatikan asas yang dinyatakan dalam ayat (1) sebagai pedoman dalam melaksanakan suatu kewenangan. Untuk di Indonesia setidaknya dapat ditetapkan dalam suatu peraturan tentang asas praduga menolak reklamasi pantai untuk zona-zona tertentu, terutama untuk daerah-daerah yang jauh di luar kawasan perkotaan.

\section{Penutup}

\section{A. Kesimpulan}

1. Reklamasi pantai dan laut telah dilaksanakan sejak lama oleh banyak negara di mana pengaturannya merupakan urusan masingmasing negara. Tetapi karena reklamasi pantai dan laut menyangkut kepentingan negara lain maka perhatian juga ditujukan kepada ketentuan UNCLOS dan instrumen internasional lain, kemudian diperkuat KTT Dunia mengenai Pembangunan Berkelanjutan di Johannesburg tahun 2002. Instrumen hukum ini diharapkan menjadi payung hukum secara internasional bagi pembangunan dan eksplorasi di wilayah laut. Sebagai negara maritim kegiatan reklamasi pantai dan laut di Indonesia dimulai dengan tindakan pemerintah melakukan kebijakan, yang landasan hukumnya dan pembuat kebijakan beraneka ragam, yaitu:

a. Pelaksanaan Reklamasi Pantai Utara Jakarta dan Reklamasi Pantai Kapuknaga Tangerang melalui Keputusan Presiden Nomor 52 Tahun 1995 tentang Reklamasi Pantai Utara Jakarta dan Keputusan Presiden Nomor 73 Tahun 1995 tentang Reklamasi Pantai Kapuknaga, Tangerang.

b. Disebagian besar daerah reklamasi pantai dan laut di Indonesia dasar hukumnya dari Surat Keputusan Pemerintah Daerah Propinsi atau Kabupaten/Kota; yang dibuat oleh pemerintah;

c. Khusus di Desa Noreh, kegiatan reklamasi pentai dan laut dilakukan oleh anggota masyarakat untuk kebutuhan perumahan, berdasarkan Surat Keputusan Pemerintah Desa. 
Dengan diundangkannya UU Nomor 27 Tahun 2007 tentang Pengelolaan Wilayah Pesisir dan Pulau-pulau Kecil yang pada Pasal 34 mengatur tentang reklamasi wilayah pesisir dan pulaupulau kecil, maka pranata hukum reklamasi pantai telah memiliki dasar hukum berupa undang-undang. Sekalipun demikian, pengaturan reklamasi dalam Pasal 34 UU Nomor 27 Tahun 2007 masih memiliki kelemahan-kelemahan, yaitu: Pengaturannya hanya dalam satu pasal saja, yaitu Pasal 34 dipandang belum dapat mengatur reklamasi pantai secara komprehensif (menyeluruh), melainkan baru secara partial saja dan Pengertian masyarakat dalam Undang-Undang Nomor 27 Tahun 2007 terbatas pada masyarakat (hukum) adat dan masyarakat lokal, dengan tambahan masyarakat tradisional, dan tidak mencakup masyarakat pesisir kawasan perkotaan yang umumnya bukan masyarakat hukum adat atau masyarakat lokal, sehingga reklamasi dalam Pasal 34 tersebut tidak mencakup masyarakat pesisir kawasan perkotaan, sementara reklamasi cenderung dilakukan di pesisir kawasan perkotaan karena pertimbangan dari sudut ekonomi.

2. Kebijakan reklamasi pantai dan laut, apalagi setelah didukung oleh ketentuan Pasal 34 Undang-Undang Nomor 27 Tahun 2007 tentang Pengelolaan Wilayah Pesisir dan Pulau-Pulau Kecil, memiliki implikasi mendesak hak-hak masyarakat pesisir. Perlindungan normatif terhadap hak-hak masyarakat pesisir berbeda-beda menurut pengelompokan pengertian masyarakat, yaitu:

a. Kesatuan-kesatuan masyarakat hukum adat dan hak-hak tradisionalnya mendapat perlindungan konstitusional dalam Pasal 18B ayat (2) UUD 1945. Jika reklamasi dilakukan di perairan pantai yang ditepinya bermukim masyarakat hukum adat akan terjadi benturan antara Pasal 18B ayat (2) dan Pasal 33 ayat (3) UUD 1945. Benturan akan bersifat terbatas sebab pada dasarnya reklamasi dilakukan di perairan pantai bukan di daratan pesisir.

b. Masyarakat lokal yang merupakan masyarakat semimasyarakat hukum adat mendapatkan perlindungan hukum melalui Pasal 60 ayat (1) UU Nomor 27 Tahun 2007. Perlindungan lebih lemah dari pada perlindungan dalam Pasal 18B ayat (2) UUD 1945.

c. Masyarakat pesisir perkotaan, sepanjang bukan merupakan masyarakat hukum adat atau masyarakat lokal, hanya 
mendapatkan perlindungan hukum secara perseorangan sepanjang ada kerugian nyata yang terjadi pada dirinya.

\section{B. Saran}

1. Perlu dibuat Undang-Undang tersendiri tentang reklamasi pantai dan laut yang mengatur reklamasi secara komprehensif (menyeluruh), mencakup hak-hak masyarakat hukum adat, masyarakat lokal, maupun masyarakat perkotaan, juga mengatur syarat-syarat, perencanaan, pelaksanaan, perlindungan dan/atau kompensasi terhadap masyarakat serta penataan dan pelestarian fungsi lingkungan hidup.

2. Masyarakat harus terlibat dalam perencanaan kebijakan lingkungan hidup. Jika reklamasi dilaksanakan harus ada kompensasi terhadap kerugian masyarakat adat, lokal, atau pesisir, sebaiknya dalam bentuk pemberdayaan masyarakat, untuk itu perlu dimasukkan sebagai tanggung jawab dan kewajiban hukum dalam undang-undang tersendiri tentang reklamasi. Selain itu perlu ditetapkan berlakunya asas praduga menolak reklamasi (presumption against reclamation) untuk zona-zona tertentu, terutama untuk daerah-daerah yang lingkungannya membutuhkan perlindungan. 


\section{Daftar Pustaka}

Muladi, H. (ed), 2005. Hak Asasi Manusia. Hakekat, Konsep dan Implikasinya dalam Perspektif Hukum dan Masyarakat. Refika Aditama, Bandung.

Anonimous, 2001. Naskah Akademik Pengelolaan Wilayah Pesisir. Dirjen Pesisir dan Pulau-Pulau Kecil Departemen Kelautan dan Perikanan, Jakarta.

, 2002. Naskah Akademik Pengelolaan Pesisir dan Laut Sulawesi Utara. DPRD Provinsi Sulawesi Utara-Fakultas Hukum Universitas Sam Ratulangi-Proyek Pesisir Sulawesi Utara, Manado, tidak dipublikasi.

Nurjaya, I Nyoman, 2000. "Proses Pemiskinan Di Sektor Sumber Daya Alam: Perspektif Politik Hukum", dalam ICRAF dan JAPHAMA, Masyarakat Adat dalam Mengelola Sumber Daya Alam, Bogor.

--, 2008. Pengelolaan Sumber Daya Alam dalam Perspektif Antropologi Hukum. Prestasi Pustaka Publisher, Jakarta.

Rawls, John, 1971. A Theory of Justice. The Belknap Press of Harvard University Press, Cambridge, Massachusetts.

2006. Teori Keadilan, terjemahan Uzair Fauzan dan Heru Prasetyo dari $A$ Theory of Justice. Pustaka Pelajar, Yogyakarta.

Schur, Edwin M., 1968. Law and Society, A Sociologikal View, New York: Random House, 1968.

Velasques, Manuel G., 2005. Etika Bisnis. Konsep dan Kasus, terjemahan Anna Purwasingsih et al dari Business Ethics, Conceps and Cases. Andi, Yogyakarta.

Wettestad, Jorgen, 1999. Designing Effective Environmental Regime. Edward Elgar Publishing, Northampton, Massachusetts. 